\title{
THE FACTORS INFLUENCING THE USAGE OF MOBILE BANKING IN INDIA
}

\section{KUMENDRA RAHEJA}

Associate Professor \& Director, Ramachandran International Institute of Management, Pune, Maharashtra, India

The Indian banking industry is poised to become the world's fifth largest by 2020 and third largest by 2025 (KPMG-CII report - "Distribution Disrupted"). The Indian banking sector comprises of 26 public sector banks, 20 private sector banks and 43 foreign banks along with 61 regional rural banks (RRBs) and more than 90,000 credit cooperatives. The impetus of the current government at the center, to expand the footprint of the banking facility to the hinterlands and to aggressively achieve the objective of financial inclusion, means that the banking industry is in for rapid expansion and growth. Given the geographical expanse of the country, the growth and expansion of this magnitude has to be ably supported by the extensive support of technology, the use of which is widely evident in the utilization of the latest technologies to conduct transactions, communicate with customers and provided better customer service. The application of Information Technology enables banks not only helps automate its processes but also communicate and connect with its customers seamlessly. With plethora of online applications in the offing, ranging from payment of bills, to conducting transactions and receiving communication, the banking industry is heavily banking on the adoption of such tech-applications as it would mean rapid expansion at a considerably low cost in comparison to the brick-and-mortar model. Through this study the author(s) intend to determine the factors that influence the usage of mobile banking services among customers. These factors are divided into two groups in terms of their impact; the first group represents the factors that drive customers to use mobile banking services, referred to as "Motivating Factors" and the secondgroup represents the factors that pose obstacles towards the use of mobile banking services, referred to as

"Inhibiting Factors". This study draws on the model proposed by Mahmood Jasim Alsamydai et al in a similar study conducted in Jordan and includes additional factors viz; intention, attitude, perceived usefulness, and the usage of mobile banking.

KEYWORDS: Banking Sector, Information Technology, Mobile Banking, Influencing Factors \& Impeding Factors

Received: Apr 04, 2019; Accepted: Apr 24, 2019; Published: May 07, 2019; Paper Id.: IJBMRJUN20194

\section{INTRODUCTION}

In the last couple decades there has been a sea-change in the ways in which companies interact with the customers. This change is fundamentally led by the propagation of and advances in internet technology [1], [2], [3] and banking sector is no exception to the roller coaster impact driven by technology. In the last few years, Indian banks have been using technology at various levels ranging from back-office processing to establish communication with customers. Indian banks currently devote around 15\% of total spending on technology and are expected to increase at an annual rate of 14.2 per cent. Banks in the country are set to benefit further as they move ahead in implementing additional technological advancements [4].

This impact of technology on banking sector is further proliferated with the increasing penetration of mobile phone usage and use of smartphones, (refer exhibit - Mobile penetration 1a, 1b \& 1c) which holds great potential to extend banking and other financial services to the people out of banking net and thereby promote 
financial inclusion. The extensive use of mobile applications for the execution of monetary transactions has come to stay with the banking industry (refer exhibit - Mobile penetration 2a $\boldsymbol{\&} \mathbf{2 b}$ ) as it provides the necessary convenience of time, cost and location to the customers. Just like the Quick Service Restaurants, internet and mobile banking has become the self-service channel for banks that allows them to provide customer services ranging from information provision to facilitating real-time monetary transactions. This has led to the adoption and implementation of internet capabilities and electronic service by many companies in financial service sector [5]. It is important to note that this type of service demands a basic knowledge of internet and technology from customers, interaction experience, and a change in the traditional banking mindset and hence form a part of the multitude of factors that would impact the adoption and usage of mobile banking services.

This research attempts to ascertain the factors that impact the usage of mobile banking services in India. The factors included in the research have been adopted from a similar study conducted in Jordan [6] and have been tested for their veracity among the Indian consumers. These factors have been explained as follows:

The factors have been grouped into 2 sets as shown below:

\section{Table 1: Factors}

SET A - Motivating Factors (termed as factors that drive the customer towards the usage of mobile banking services). It include the following sub-factors:

Ease of use, Assurance, Speed of transaction, Pursuance and Communication

SET B - Inhibiting Factors (termed as factors that inhibit the customer from using the mobile banking services). It include the following sub-factors:

Personal desires, Personal knowledge, Habit, Resistance to innovation and Experience

\section{RESEARCH BACKGROUND \& OBJECTIVES}

This study was undertaken to examine the effect of motivating and inhibiting factors on the usage of Mobile banking services in India. The findings from this study would help the marketers to adjust their marketing strategies to reinforce and focus on the motivating factors in the promotion of mobile banking usage; simultaneously work towards reducing the impact of inhibiting factors in consumer mindset by addressing the fears in their mind pertaining to mobile banking usage. Under this premise, the research objectives enumerated below are relevant and worthy of examination:

- To ascertain the factors that motivate the usage of mobile banking.

- To ascertain the factors that inhibit the usage of mobile banking.

- To ascertain the extent to which perceived usefulness, attitude and intention affect the mobile banking usage.

\section{Study Model}

The model used for this research draws on the studies that have been conducted in the past and have mention in the marketing literature [6], [7] \& [8]. For the model (refer exhibit 3). The model depicts the relationship between various constructs under study in the current research.

\section{LITERATURE REVIEW}

Enumerated below is the literature review related to motivating and inhibiting factors: 


\section{Motivating Factors}

\section{Ease of Use}

Perusing the past decade research data provides a substantial indication of the noteworthy effect of ease of use on perceived usefulness [9]-[14]. Any technology interface must inherently have ease-to-learn and ease-to-use built into it else it would obstruct the intended users from using it and mobile banking systems are no exception. This study examines the effect of ease of use on perceived usefulness of mobile banking.

\section{Assurances}

Trust is one of the most important elements of building \& sustaining relationship between any two parties and various studies have established that assurances augment trust. These could be of different types like guarantees, contracts, policies, agreements, laws, regulations, feedback forums, and others [15] - [17]. This study examines the effect of assurances on the perceived usefulness of mobile banking.

\section{Speed of Transactions}

The offline banking transactions tend to consume more time as compared to online banking transactions and few studies have also discussed the importance of speed of transactions in mobile banking and assert that the time taken to accomplish similar banking transactions online is lesser as compared to offline banking (i.e.) the speed of transaction has a favorable impact on customer's perceived usefulness of mobile banking. This study examines the effect of speed of transactions on the perceived usefulness of mobile banking.

\section{Pursuance}

In today's fast paced world, it is absolutely necessary to have facilities that can provide "on-the-go" and "on-demand" information and banking is no exception. Mobile banking allows the customers to stay up-to-date with their transactions as and when they need. Various studies show that intention to use mobile banking is considerably impacted by perceived usefulness of mobile banking and it's utility [18] \& [19]. This study examines the effect of pursuance on the perceived usefulness of mobile banking.

\section{Communication}

Mobile phone can double up as an additional channel available to banks to interact with their customers and for customers to access information related to offers and latest updates [20] making it an exhaustive channel for banking transactions. This study examines the effect of communication on the perceived usefulness of mobile banking.

\section{Inhibiting Factors}

\section{Personal Desire}

Research review suggests that personal desire of the customers negatively affects perceived usefulness of mobile banking [21] \& [22] (i.e.) any decrease in the desire to use mobile banking will adversely affect the perceived usefulness of mobile banking service. This study examines the effect of personal desire on perceived usefulness of mobile banking.

\section{Experience}

The literature suggests that the mobile banking usage is impacted by the experience of using mobile banking although the degree varies as its usage is dependent upon technical system and the skill and/or experience of the customer. 
The literature shows association between mobile banking experience and its perceived usefulness [23]. This study examines the effect of experience on the perceived usefulness of mobile banking.

\section{Resistance to Innovations}

Multiple researches, in this domain, have been conducted in the last couple of decades. In general, through the constructs of perceived usefulness and perceived ease of use of technology, it has been shown that resistance to innovations influences behavioral intention to accept technology [24]. Specific to mobile banking, a study has established through usefulness and ease of use constructs that there is considerable influence of customers' resistance to mobile banking on their intention [25]. In yet another study, the researchers claim that any increase in the resistance to mobile banking would affect the use of mobile banking adversely [26]. Further, a study suggests that the functional and psychological barriers to innovation adversely affect the adoption of mobile banking [27]. These studies point out that there is an inverse relationship between the resistance to innovation and intention to use mobile banking services. This study examines the impact of resistance to innovation on the perceived usefulness of mobile banking services.

\section{Habit}

'Habit impacts the perceived usefulness' and this has been explained in mobile banking context as well [28], [29]. Habit of performing offline transactions with the banks prevents the usage of mobile banking services. This study examines the impact that habit has on the perceived usefulness of mobile banking.

\section{Knowledge}

Several studies have come to reveal that customer's limited knowledge about mobile banking services \& systems impacts its perceived usefulness and such customers are more likely to stick to traditional mode of banking. [28] - [31]. In the current study, we examine the impact of knowledge on the perceived usefulness of mobile banking services.

\section{Perceived Usefulness of Mobile Banking}

"It is the degree to which a person believes that using a particular system would enhance his or her job performance [24].

"The extent to which an individual believes that he or she would benefit from using mobile banking" there by emphasizing the importance of perceived usefulness in the domain of mobile banking services [28], [32] - [36]

Within the mobile banking literature, it is abundantly found that there is positive relationship between the perceived usefulness of mobile banking, intention and attitude towards mobile banking and the usage of mobile banking. [10], [12] - [14], [16], [32], [34] \& [37]. In this study we examine the relationship between customer's perceived usefulness of mobile banking and the usage of this service.

\section{Attitude toward Mobile Banking}

Consumer behavior literature has extensive mention of attitude towards mobile banking and shows that customer's perceive usefulness influences attitudes and intention towards mobile banking of mobile banking. It further establishes that a significant part is played by attitude towards behavior in envisaging and understanding consumer intention and behavior (mobile banking usage) [16], [38] - [42]. In this study, we examine the impact of attitude towards mobile banking on the usage of mobile banking service. 


\section{Intention toward Mobile Banking}

"Behavioral intention refers to an individual's willingness to perform or not to perform, a specific future behavior"

Like attitude, intention too is considered an important predictor of an individual's behavior [39] \& [44] and has received considerable importance in consumer behavior literature.

In light of these studies, we examine the impact of intention towards mobile banking on the usage of mobile banking service.

\section{Usage of Mobile Banking}

The ultimate construct of this study is the usage of mobile banking.

The existence of consumer's attitude and intention towards mobile banking usage is required across the process of mobile banking transactions. [16] \& [45].

In this study we examine the association between customer's perceived usefulness and the usage of mobile banking service.

\section{Hypotheses}

This study intends to test the following hypothesis:

H1: There is a considerable positive effect of motivating factors on consumer's mobile banking service usage.

H2: There is a considerable negative effect of inhibiting factors on consumer's mobile banking service usage.

H3: There is a considerable positive effect of perceived usefulness on consumer's mobile banking service usage.

H4: There is a considerable positive effect of customer's attitude on consumer's mobile banking service usage.

H5: There is a considerable positive effect of customer's intention on consumer's mobile banking service usage.

H6a: There is a considerable influence of motivating factor, perceived usefulness, customer's attitude and intention toward mobile banking on him/her accepting the mobile banking service usage.

H6b: There is a considerable influence of inhibiting factor, perceived usefulness, customer's attitude and intention toward mobile banking on him/her not accepting the mobile banking service usage.

\section{RESEARCH METHODOLOGY}

The sample design was decided by taking into consideration the nature of the research and other related factors. The researcher has chosen non-probability purposive sampling. The sample size was arrived at by employing the following formula:

$$
\mathbf{n}=\mathbf{N Z}^{2}(\mathbf{p q}) / \mathbf{N T}^{2}+\mathbf{Z}^{2}(\mathbf{p q})
$$

(Mishra M.N, pp 176; Kothari C.R., 2008, pp 179) 
Table 2: Sample Calculation Formula

\begin{tabular}{|c|l|}
\hline $\mathbf{n}$ & adjusted sample size \\
$\mathbf{Z}$ & $\begin{array}{l}\text { level of confidence }=1.96 \text { (for } 95 \% \\
\text { confidence level) }\end{array}$ \\
\hline $\mathbf{T}$ & $\begin{array}{l}\text { allowable tolerance of variation / margin of } \\
\text { error }=5 \% \text { or.05 }\end{array}$ \\
\hline $\mathbf{N}$ & population size \\
\hline $\mathbf{p}$ & probability of occurring the event $=75 \%$ or.75 \\
\hline $\mathbf{q}$ & $\begin{array}{l}\text { probability of non-occurring the event }=25 \% \\
\text { or.25 }\end{array}$ \\
\hline
\end{tabular}

As per the date of Reserve Bank of India (RBI), the volume of mobile banking uses in India as on 26 March 2017 was 48.5 million (refer exhibit 4)

Therefore, the sample size for consumer survey $=\mathbf{2 8 9}$ (refer calculations below)

$$
\begin{aligned}
& \mathbf{n}=48500000(1.96)^{2} *(0.75 * 0.25) / 48500000 \\
& (0.05)^{2}+(1.96)^{2} *(0.75 * 0.25) \\
& \mathbf{n}=48500000 \times 3.8416 \times 0.1875 / 48500000 * \\
& (.0025)+3.8416 * 0.1875 \\
& \mathbf{n}=34934550 /(121250+0.7203) \\
& \mathbf{n}=34934550 / 121250.7203 \\
& \mathbf{n}=\mathbf{2 8 8 . 1 1 8 2}
\end{aligned}
$$

Universe: All the people who are active users of mobile banking services in India.

\section{Data Sources}

Primary Data: Collected from the intended respondents with the help of a structured questionnaire.

Secondary Data: Related literature review\& internet.

The study model and questionnaire was adopted from a similar study conducted in Jordan with a modification of inclusion of $\mathbf{1 7}$ items in place of original 19 items. The questionnaire uses a 5-point Likert Scale to measure all the focal constructs, where 1 stands for “To no extent” and 5 stand for “To a very great extent”.

\section{Data Analysis}

The data was analyzed with the help of statistical package SPSS 21.0. The analysis included Cronbach's Aplha validity test, descriptive and frequency analysis. To test the hypothesis, the single sample T-test was used where higher value (based on the value of scale mid-point) denotes more favorable attitude and vice versa.

\section{RESULTS}

\section{Reliability test}

The researcher undertook the Cronbach's Alpha Reliability Test to ensure high degree of internal consistency among the set of indicators (questionnaire items - Exhibit 5). The Cronbach's alpha value above.6 is considered to be a 
healthy indicator of high degree of internal consistency among questionnaire items. The test was carried out on the pilot study of 37 customers.

Case Processing Summary

Table 3: Result of Cronbach's Alpha Reliability Test

\begin{tabular}{|c|c|c|c|}
\hline & & $\mathrm{N}$ & $\%$ \\
\hline \multirow{2}{*}{ Cases } & Valid & 37 & 100.0 \\
\hline & Total & 37 & 100.0 \\
\hline \multicolumn{4}{|c|}{ Reliability Statistics } \\
\hline \multicolumn{2}{|c|}{ Cronbach's Alpha } & & of Items \\
\hline \multicolumn{2}{|c|}{0.789} & & 17 \\
\hline
\end{tabular}

\section{Descriptive Analysis}

The data was subjected to descriptive analysis to find out the mean and it was found that the except questions 7 - "To what extent does your personal knowledge affect your usage of Mobile Banking Services" and question 9 - "To what extent does your Resistance to innovation affect your usage of Mobile Banking Services", the mean for all other questions was over the mid-point (3). The results are shown in the table below:

Table 4: Descriptive Analysis

\begin{tabular}{|c|c|c|c|c|}
\hline $\begin{array}{c}\text { Questionnaire } \\
\text { Item }\end{array}$ & Mean & $\begin{array}{c}\text { Std. } \\
\text { Dev. }\end{array}$ & T. & $\begin{array}{c}\text { Sig(2) } \\
\text { Tailed }\end{array}$ \\
\hline 1 & 3.34 & 1.37 & 3.82 & .000 \\
\hline 2 & 3.43 & .91 & 7.27 & .000 \\
\hline 3 & 3.26 & 1.16 & 2.79 & .005 \\
\hline 4 & 3.47 & .89 & 9.67 & .000 \\
\hline 5 & 3.38 & .97 & 7.79 & .000 \\
\hline 6 & 3.76 & 1.07 & 13.96 & .000 \\
\hline 7 & 2.87 & 1.02 & 1.69 & .007 \\
\hline 8 & 3.63 & 1.05 & 13.27 & .000 \\
\hline 9 & 2.74 & 1.27 & 4.87 & .000 \\
\hline 10 & 3.87 & 1.01 & 15.07 & .004 \\
\hline 11 & 3.39 & 1.07 & 5.54 & .000 \\
\hline 12 & 3.37 & 1.11 & 5.01 & .003 \\
\hline 13 & 3.66 & 1.10 & 10.54 & .000 \\
\hline 14 & 3.66 & .92 & 6.94 & .000 \\
\hline 15 & 3.90 & 1.01 & 1.94 & .001 \\
\hline 16 & 4.08 & .79 & 25.44 & .000 \\
\hline 17 & 3.65 & .85 & 18.35 & .000 \\
\hline
\end{tabular}

\section{Hypotheses Testing}

The hypotheses were tested for their acceptance/rejection through mean score analysis and one sample t-test.

The table below shows the result of the statistical analysis:

Table 5: Hypotheses Testing

\begin{tabular}{|c|c|c|c|c|}
\hline $\begin{array}{c}\text { Questionnaire } \\
\text { Item }\end{array}$ & Mean & $\begin{array}{c}\text { Std. } \\
\text { Dev. }\end{array}$ & T. & $\begin{array}{c}\text { Sig(2) } \\
\text { Tailed }\end{array}$ \\
\hline H1 & 3.38 & .612 & 11.02 & .000 \\
\hline H2 & 3.33 & .528 & 10.36 & .000 \\
\hline H3 & 3.47 & .855 & 9.25 & .000 \\
\hline H4 & 3.54 & .836 & 11.31 & .000 \\
\hline
\end{tabular}




\begin{tabular}{|c|c|c|c|c|}
\hline \multicolumn{5}{|c|}{ Table 5: Contd., } \\
\hline H5 & 3.49 & .941 & 10.42 & .000 \\
\hline H6a & 3.95 & .624 & 28.27 & .000 \\
\hline H6b & 4.01 & .74 & 26.17 & .000 \\
\hline
\end{tabular}

As seen from the table above the mean value is more than the midpoint (3) with minor dispersion in standard deviation. For further validation, one sample t-test was carried out which reveals that the overall mean difference as a whole is statistically significant $(\mathrm{N}=0.000)$ at $(\mathrm{Ns}=0.05)$ with a high $\mathrm{T}$-value $(\mathrm{t}>1.96)$. Hence all the hypotheses are validated.

\section{DISCUSSIONS \& CONCLUSIONS}

This study aimed to ascertain the factors that impact the usage of mobile banking services. The study took into consideration the motivation factors, inhibiting factors, perceived usefulness, attitude, intention and mobile banking usage. Overall 6 hypotheses were formulated with two divisions of hypothesis 6 and were testing the factors impacting the mobile banking usage. These hypotheses were tested with the help of mean score analysis and one sample t-test ( $T$ value).

From the analysis, it was found that the responses to all questions were positive except for question 7 and 9 as the mean score for these questions was less than the mid-point 3. Questionnaire item no 16, which corresponds to the effect of motivating factors on the acceptance of usage of mobile banking services, recorded the highest mean value (4.08) and $t$ value (25.44) ascertaining that the acceptance of usage of mobile banking services is positively affected by motivating factors. Considerably high mean score (3.65) and t-value (18.35) for questionnaire item no 17 , ascertains that the acceptance of the usage of mobile banking services is adversely affected by inhibiting factors.

Among the motivating factors, ease of use (questionnaire item no. 4) has the highest mean score of 3.47 which is closely followed by speed (questionnaire item no. 2) with a mean score of 3.43. The least mean is scored by communication (questionnaire item no 3). This shows that the usage of mobile banking services is impacted by all the motivating factors in varied degree with ease of use being the highest and communication being the lowest.

Among the inhibiting factors, experience (questionnaire item no 10) has the highest mean score of 3.87 which is closely followed by personal desires with a mean score of 3.76 (questionnaire item no 6) indicating an effect on customer's usage of mobile banking services. Personal knowledge (2.87)and resistance to innovation (2.74) are two such factors whose mean value is less than the mid-point 3 hence they are considered to have negative effect on the usage of mobile banking services.

This study also found out that perceived usefulness positively effects attitude, intention and the usage of mobile banking services (questionnaire item no 11,12 \& 13) which has the mean score of 3.39, 3.37 and 3.66 respectively. Additionally, it is found that attitude (questionnaire item no 14) and intention (questionnaire item no 15) have a positive effect on the usage of mobile banking services.

Lastly, the study found that motivating factors (mean score 4.08 - questionnaire item no 16) and inhibiting factors (mean score 3.65 - questionnaire item no 17) affect the usage of mobile banking services with the former having more significant effect than the latter.

Overall, all the hypotheses are validated and the results of this study conforms to the result of most of the studies conducted in the domain of mobile banking services as indicated in the literature review. 


\section{REFERENCES}

1. E. Ibrahim, M. Joseph, and K. Ibeh, "Customers' perception of electronic service delivery in the UK retail banking sector," International Journal of Bank Marketing, vol. 24, pp. 475-493, 2006.

2. H. Bauer, M. Hammerschmidt, and T. Falk, "Measuring the quality of e-banking portals," International Journal of Bank Marketing, vol. 23, pp. 153-175, 2005. International Journal of Computer Theory and Engineering, Vol. 4, No. 6, December 20121023

3. A. Parasuraman and G. Zinkhan, "Marketing to and serving customers through the internet: An overview and research agenda," Journal of the Academy of Marketing Science, vol. 3, pp. 286-295, 2002.

4. Indian Brand Equity Foundation Report - February 2017; www.ibef.org

5. S. Rotchanakitumnuai and M. Speece, “Corporate customer perspectives on business value of thai internet Banking," Journal of Electronic Commerce Research, vol. 5, pp. 270-286, 2004.

6. M. Alsamydai, S. Yassen, H. Alnaimi, D. Dajani \& Al-Qirem5, "the factors influencing customer usage of mobile banking services in Jordan", International Journal of Business Management \& Research (IJBMR), ISSN(P): 2249-6920; ISSN(E): 2249-8036, Vol. 4, Issue 2, Apr 2014, 63-78.

7. Yong, K. L., Jong-Hyun, P., \& Nambo C. (2009). An exploratory study on factors affecting usage intention toward mobile banking: A unified perspective using structural equation modeling. Society for Marketing Advances Proceedings, p347.

8. Dikit, S.V, Shringorpure, A.A, \& Pathan, F.D.N (2012). Strategies to make mobile banking popular in India, Advances in Management, 5 (13), 6

9. Agarwal, R., \& Prasad, J. (1999). Are individual differences germane to the acceptance of new information technologies? Decision Sciences, 30(2), 361-391.

10. Davis, F.D. (1989). Perceived usefulness, perceived ease of use and user acceptance of information technology MIS Quarterly, 13(3), 319-340.

11. Hu, P. J., Chau, P. Y. K., Sheng, O. R. L., \& Tam, K. Y. (1999). Examining the technology acceptance model using physician acceptance of telemedicine technology. Journal of Management Information Systems, 16(2), 91-112.

12. Toby, A. (2014). Working capital management policy and corporate profitability of Nigerian quoted companies: A sectoral analysis. International Journal of Financial Management, 3(1), 9-20.

13. Venkatesh, V. (2000). Determinants of perceived ease of use: integrating control, intrinsic motivation, and emotion into the technology acceptance model. Info. Syst. Res. 4(4), 342-365.

14. Venkatesh, V., \& Davis, F. D. (2000). A theoretical extension of the technology acceptance model: Four longitudinal field studies. Management Science, 46(2), 186-204.

15. Venkatesh, V., \& Morris, M. G. (2000). Why don't men ever stop to ask for directions? Gender, social influence, and their role in technology acceptance and usage behavior. MIS Quarterly, 24(1), 115-139.

16. McKnight, D.H., Kacmar, C.J. \& Choudhury, V. (2004). Shifting factors and the ineffectiveness of third party assurance seals: A two-stage model of initial trust in a web business. Electronic Markets, 14, 252-266.

17. Pavlou, P. (2003). Consumer acceptance of electronic commerce: Integrating trust and risk with the technology acceptance model. International Journal of Electronic Commerce, 7(3), 101-134. 
18. Pavlou, P.A. \& Gefen, D. (2004). Building effective online marketplaces with institution based trust. Information Systems Research, 15, 37-59.

19. Haque, A., Tarofder, A., Rahman, S., \& Raquib, A. (2009). Electronic transaction of internet banking and its perception of Malaysian online customers. African Journal of Business Management, 3(6), 248-259.

20. Vijayakumar, A., \& Jayachitra, S. (2013). M-banking in India: A strategic analysis of issues and challenges. International Journal of Development Research, 3(11), 150-158.

21. Clark, A. (2008). Mobile banking \& Switching - White Paper. pdf.

22. Staff (2006). Survey: U.S. Cell Phone Users Want Same Mobile Commerce Services and Biometric Protection that are Available in Asia.

23. Cook, A., \& Goette, T. (2006). Mobile Electronic Commerce: What Is It? Who Uses It? And Why Use It? Communications of the IIMA, 6(4), 49-57.

24. Chung, M., \& Kwon, S. (2009). The effects of customers' mobile experience and technical support on the intention to use mobile banking. Cyber psychology \& Behavior, 12(5), 539-543.

25. Davis, F.D. (1989). Perceived usefulness, perceived ease of use and user acceptance of information technology.MIS Quarterly, 13(3), 319-340.

26. Rammile, N., \& Nel, J. (2012). Understanding resistance to cell phone banking adoption through the application of the technology acceptance model (TAM). African Journal of Business Management, 6(1), 86-97.

27. Barati, S., \& Mohammadi, S. (2009). An efficient model to improve customer acceptance of mobile banking, Proceedings of the World Congress on Engineering and Computer Science (WCECS 2009), San Francisco, CA, October 20-22.

28. Alsamydai, M. J., Yassen, S. G., \& ALnaimi, H. M. (2014). the factors influencing customer usage of mobile banking services in Jordan. International Journal Of Business Management and Research, 4(2), 63-78.

29. Laukkanen, T., \& Cruz, P. (2010). What determines mobile banking non-adoption? Proceedings of ANZMAC,available at: http://anzmac2010.org/proceedings/pdf/ANZMAC10Final00387.pdf.

30. Laforet, S., \& Li, X. (2005). Consumers' attitudes towards online and mobile banking in China. International Journal of Bank Marketing, 23(5), $362-380$

31. Servon Q., \& Kaestner B. (2008). Internet banking: where does India stand?. Journal of Contemporary management, 2(1), 3858.

32. Corritore, C. L., Kracher, B., \& Wiedenbeck, S. (2003). On-line trust: Concepts, evolving themes, a model. International Journal of Human-Computer Studies, 58, 737-758.

33. Gerrard, P., Cummingham, F. B., \& Devlin, F. F. (2006). Why consumers are not using internet banking: A qualitative study. Journal of Service Research, 20(3), 160-168.

34. Bhatti, T. (2007). Exploring Factors Influencing the Adoption of Mobile Commerce. Journal of Internet Banking and Commerce, 12(3), 1-13.

35. Guriting P., \& Ndubisi, N.O (2006). Borneo online banking: evaluating customer perceptions and behavioral intention. Manage. Res. News, 29(1/2), 6-15.

36. Kim, H.W., Chan, H.C., \& Gupta, S. (2007). Value-based Adoption of Mobile Internet: An empirical investigation. Decision Support Systems, 43(1), 111-126. 
37. Liao, Z., \& Cheung, M.T (2002). Internet-based e-banking and consumer attitudes: an empirical study. Info. Manage. 39(4), 283-295.

38. Polatoglu, V.N., \& Ekin, S. (2001). An empirical investigation of the Turkish consumers' acceptance of internetbanking services. International Journal of Bank Mark, 19(4), 156-165.

39. Gefen, D., \& Straub, D.W. (2000). The relative importance of perceived ease of- use in IS acceptance: A study of e-commerce acceptance. Journal of AlS, 1(8), 1-30.

40. Ajzen, I. (1991). The Theory of Planned Behaviour. Organizational Behaviour and Human Decision Processes, 50(2), 179211.

41. Ajzen, I. (2002). Perceived behavioral control, self-efficacy, locus of control, and the theory of planned behaviour. Journal of Applied Social Psychology, 32, 665-683.

42. Ajzen, I. (2005). Attitudes, Personality and Behaviour. (2nd ed). Open University Press.

43. Alsamydai, Mahmood. Jasim., Yousif, Rudaina., \& Ihab Ali Al-Qirem. (2013). Measuring individual attitude towards ArabicSpeaking TV channels and the impact of these channels on current events. International Journal of Business and Management, $8(1), 73-88$.

44. Smith, J., Terry, D., Manstead, A., Louis, W., Kotterman, D., \& Wolfs, J. (2008). The attitude-behaviour relationship in consumer conduct: The role of norms, past behavior, and self-identity. The Journal of Social Psychology, 148(3), 311-333.

45. Asantey, J. O., \& Tengey, S. (2014). The determinants of bad loans in financing small and medium-size enterprises in the banking sector in Ghana: A factorial analysis approach. International Journal of Research in Business Management, 2(11), $13-26$.

46. Konerding, U. (1999). Formal models for predicting behavioral intentions in dichotomous choice situations. Methods of Psychological Research, 4(2), 1-32.

47. Castañeda, J. A., Muñoz-Leiva, F., \& Luque, T. (2007). Web Acceptance Model (WAM): Moderating effects of user experience. Information \& Management, 44(4), 384-396.

48. Moon, J-M., \& Kim, Y-G. (2001). Extending the TAM for a World-Wide-Web context, information and Management, 28, $217-$ 230.

\section{APPENDIX}

\section{Exhibits}

\section{Mobile Penetration}

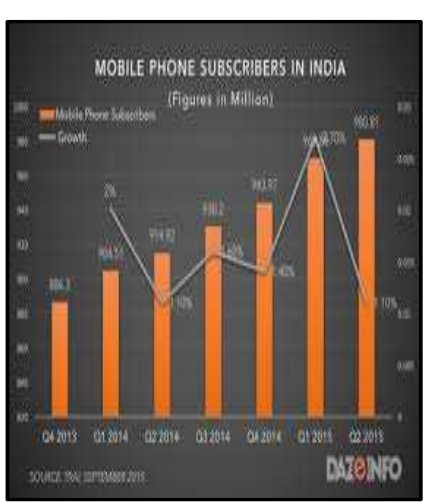

Exhibit 1a

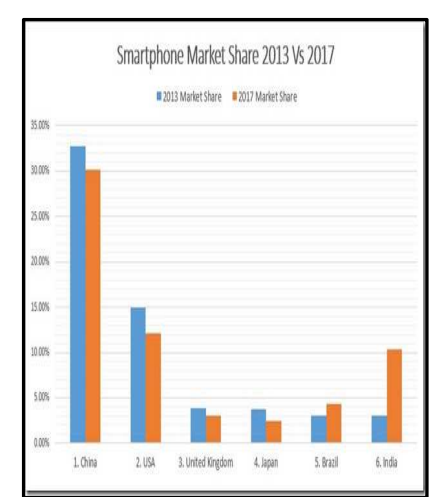

Exhibit 1b

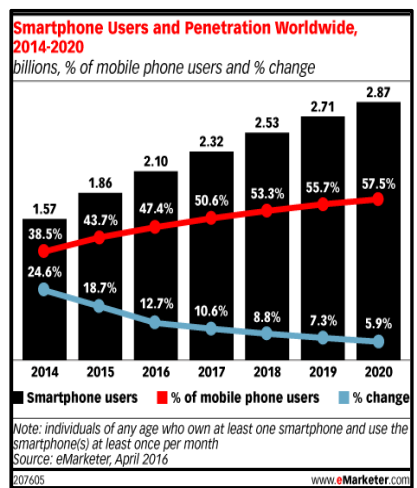

Exhibit1c 


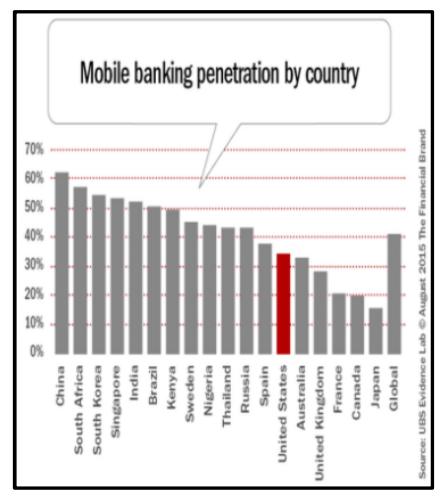

Exhibit 2a

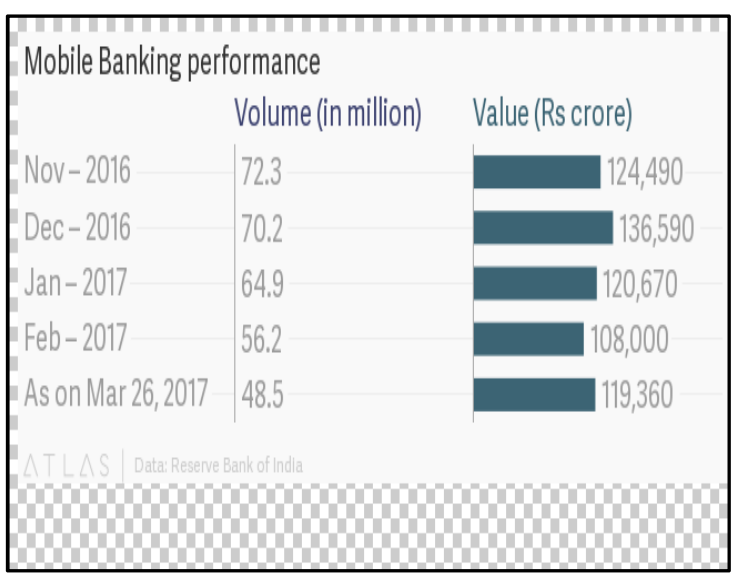

Exhibit 3 - Study Model

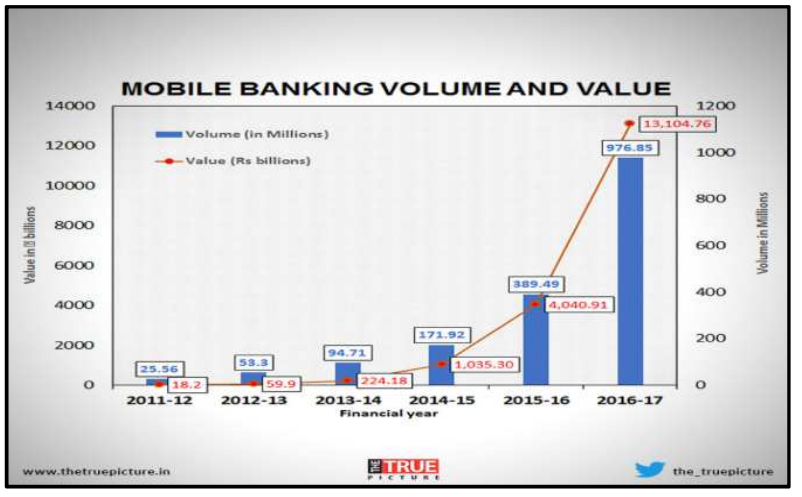

Exhibit 2b

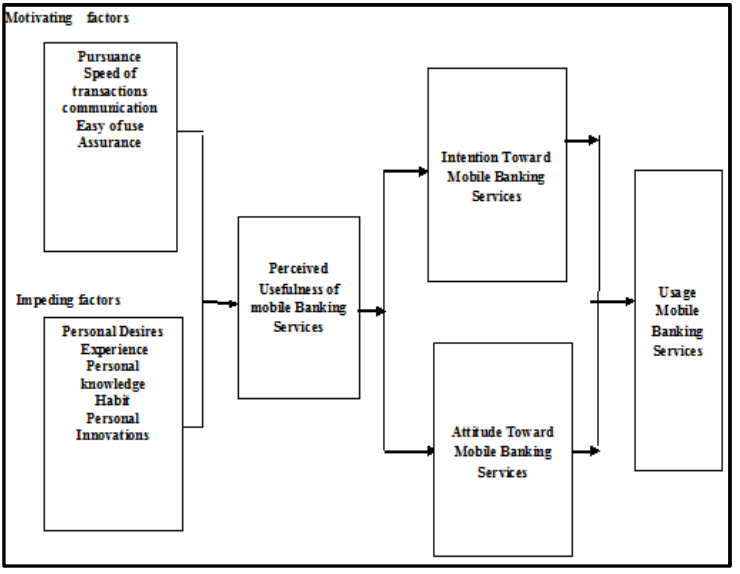

Exhibit 4 - Mobile Banking Performance

Exhibit 5 - Questionnaire Items

\begin{tabular}{|l|l|c|l|}
\hline $\mathbf{1}$ & $\begin{array}{l}\text { To what extent does pursuance affect your } \\
\text { usage of Mobile Banking Services }\end{array}$ & $\mathbf{1 0}$ & $\begin{array}{l}\text { To what extent does your experience affect your usage } \\
\text { of Mobile Banking Services }\end{array}$ \\
\hline $\mathbf{2}$ & $\begin{array}{l}\text { To what extent does speed affect your usage of } \\
\text { Mobile Banking Services }\end{array}$ & $\mathbf{1 1}$ & $\begin{array}{l}\text { To what extent does perceived usefulness affect your } \\
\text { attitude to usage Mobile Banking Services }\end{array}$ \\
\hline $\mathbf{3}$ & $\begin{array}{l}\text { To what extent do communications affect your } \\
\text { usage of Mobile Banking Services }\end{array}$ & $\mathbf{1 2}$ & $\begin{array}{l}\text { To what extent does perceived usefulness affect your } \\
\text { intention to usage of Mobile Banking Services }\end{array}$ \\
\hline $\mathbf{4}$ & $\begin{array}{l}\text { To what extent does ease of use affect your } \\
\text { usage of Mobile Banking Services }\end{array}$ & $\mathbf{1 3}$ & $\begin{array}{l}\text { To what extent does your perceived usefulness affect } \\
\text { your usage of Mobile Banking Services }\end{array}$ \\
\hline $\mathbf{5}$ & $\begin{array}{l}\text { To what extent does assurance affect your } \\
\text { usage of Mobile Banking Services }\end{array}$ & $\mathbf{1 4}$ & $\begin{array}{l}\text { To what extent does your attitude affect your usage of } \\
\text { Mobile Banking Services }\end{array}$ \\
\hline $\mathbf{6}$ & $\begin{array}{l}\text { To what extent do your personal desires affect } \\
\text { your usage of Mobile Banking Services }\end{array}$ & $\mathbf{1 5}$ & $\begin{array}{l}\text { To what extent does your intention affect your usage of } \\
\text { Mobile Banking Services }\end{array}$ \\
\hline $\mathbf{7}$ & $\begin{array}{l}\text { To what extent does your personal knowledge } \\
\text { affect your usage of Mobile Banking Services }\end{array}$ & $\mathbf{1 6}$ & $\begin{array}{l}\text { Do motivation factors, perceived usefulness, your } \\
\text { attitude and intention toward Mobile Banking make you } \\
\text { accept using of Mobile Banking Services }\end{array}$ \\
\hline $\mathbf{8}$ & $\begin{array}{l}\text { To what extent does your habit affect your } \\
\text { usage of Mobile Banking Services }\end{array}$ & $\mathbf{1 7}$ & $\begin{array}{l}\text { Do impeding factors, perceived usefulness, your attitude } \\
\text { and intention toward Mobile Banking make you not } \\
\text { accept using of Mobile Banking Services }\end{array}$ \\
\hline $\mathbf{9}$ & $\begin{array}{l}\text { To what extent does your Resistance to } \\
\text { innovation affect your usage of Mobile } \\
\text { Banking Services }\end{array}$ & & \\
\hline
\end{tabular}

